\title{
PELAKSANAAN PERLINDUNGAN HUKUM BAGI PEKERJA PEREMPUAN PADA BESAKIH BEACH HOTEL SANUR DI DENPASAR*
}

\author{
Oleh: \\ I Wayan Agus Sumandika** \\ I Nyoman Mudana*** \\ Program Kekhususan Hukum Bisnis \\ Fakultas Hukum Universitas Udayana
}

\begin{abstract}
Abstrak:
Pekerja perempuan mempunyai hak untuk mendapatkan perlindungan. Perlindungan yang dimaksudkan adalah perlindungan atas kesehatan, kesusilaan, keselamatan, pemeliharaan moril kerja serta perlakuan yang sesuai dengan moral dan martabat manusia. Hotel Besakih Beach Denpasar memiliki peranan penting dalam mengembangkan sektor pariwisata agar semakin maju, maka perlindungan hukum bagi pekerja perempuan menjadi sangat diperlukan dalam operasi kerjanya. Adapun permasalahan yang diangkat dalam tulisan ini diantaranya pengaturan perlindungan hukum bagi pekerja perempuan di sektor perhotelan dan kendala-kendala yang dihadapi dalam pelaksanaan perlindungan hukum bagi pekerja perempuan di sektor perhotelan. Penelitian ini merupakan penelitian hukum empiris yang meneliti fenomena hukum yang terjadi di lapangan. Dalam penelitian ini digunakan sumber data. Data primer merupakan data yang diperoleh secara langsung dari keterangan-keterangan pihak terkait di lapangan sedangkan data sekunder berasal dari penelitian pustaka yaitu peraturan perundang-undangan, literatur, dan buku-buku yang terkait. Dari hasil penelitian ini dapat disimpulkan bahwa perlindungan hukum yang sudah dilaksanakan adalah pekerja perempuan harus berumur delapan belas tahun, waktu istirahat atau cuti, upah bagi pekerja, uang lembur, tempat tinggal bagi tenaga kerja,

${ }^{*}$ Penulisan Karya Ilmiah berjudul Pelaksanaan Perlindungan Hukum Bagi Pekerja Perempuan Pada Besakih Beach Hotel Sanur di Denpasar, jurnal ini merupakan ringkasan skripsi penulis.

${ }^{* *}$ I Wayan Agus Sumandika, 1116051193 , Mahasiswa S1 Reguler Sore, E-mail: sumandikaagus@gmail.com Udayana.

${ }_{* * *}$ I Nyoman Mudana, SH.,MH, Dosen Tetap Fakultas Hukum Universitas
\end{abstract}


menjaga kesusilaan dan keamanan ditempat kerja dan memberikan fasilitas Pertolongan Pertama Pada Kecelakaan. Kendala yang ditemui dalam pelaksanaan perlindungan hukum bagi pekerja perempuan bukan saja dari pihak perusahaan namun juga dari pihak pekerja. Sebagian besar pekerja perempuan di Hotel Besakih Beach Denpasar kurang menyadari dan tidak menggunakan hak-hak dari perlindungan hukum yang mereka peroleh.

Kata Kunci: Perlindungan Hukum, Pekerja, Perempuan

\begin{abstract}
:
Female workers have the right to protections. The protections is intended to protect health, decency, safety, maintenance of work morale and treatment that is in accordance with human morality and dignity. Besakih Beach Hotel Denpasar has an important role in developing the tourism sector to be more advanced, then legal protection for women workers becomes indispensable in its work operations. The issues raised in this paper include the legal protection arrangements for female workers in the hospitality sector and the obstacles of implementing legal protection for female workers in the hospitality sector. This research is an empirical legal research that examines legal phenomena that occur in the field. In this study data sources were used. Primary data is data obtained directly from the statements of related, while secondary data comes from library research, namely legislation, literature, and related books. From the results of this study it can be concluded that legal protection that has been carried out is female workers must be eighteen years old, rest or leave time, wages for workers, overtime money, shelter for workers, maintaining decency and security at work and providing First Aid facilities on accident. Constraints encountered in implementing legal protection for female workers are not only from the company but also from the workers. Most female workers at Besakih Beach Hotel Denpasar are less aware and do not use the rights of legal protection they obtain.
\end{abstract}

Keywords: Law Protection, Labor, Female

\title{
I. PENDAHULUAN
}

\subsection{Latar Belakang}

Dalam ketentuan Pasal 27 ayat (2) Undang-undang Dasar 1945 disebutkan "bahwa setiap warga negara mempunyai hak atas pekerjaan dan penghidupan yang layak bagi manusia.” 
Istilah "setiap warga negara" dapat berarti hak tersebut berlaku bagi semua warga negara baik perempuan maupun laki-laki, tidak ada bias gender dan pembedaan dari jenis kelamin di dalamnya. Namun hingga dewasa ini, masih terjadi ketimpangan gender yang begitu kentara pada dunia kerja. Kedudukan kaum laki-laki masih dianggap lebih penting dari kedudukan kaum perempuan sehingga peluang dan kesempatan yang diperoleh kaum laki-laki lebih besar sedangkan perempuan di berbagai sektor masih dibatasi.

Adanya gerakan emansipasi wanita dalam pemenuhan persamaan hak kaum laki-laki dan perempuan menjadikan kaum perempuan lebih terdorong untuk berperan aktif dalam kegiatan ekonomi dan sosial. Perempuan bukan lagi kaum yang bekerja di sektor domestik namun telah merambah ke sektor publik. Peluang tersebut semakin nyata dan terbuka didukung dengan banyaknya jumlah kaum perempuan yang telah berpendidikan. Kedudukan Perempuan dalam dunia kerja tidak dapat dipandang sebelah mata. Banyaknya jumlah kaum perempuan yang memasuki dunia kerja pada saat ini menunjukkan keberadaan perempuan dalam dunia usaha semakin penting dan dibutuhkan.

Meningkatnya perkembangan pariwisata di Bali menyebabkan tumbuhnya usaha perhotelan yang semakin menjamur. Kebutuhan akan tenaga kerja terampil di sektor perhotelan menjadi faktor pendukung yang krusial dalam menyokong industri ini. Tidak hanya menyerap pekerja laki-laki namun juga melibatkan pekerja perempuan. Tidak dipungkiri pekerja perempuan memiliki andil yang besar dalam industri perhotelan.

Pekerja perempuan yang terjun di dunia industri perhotelan terdiri dari pekerja perempuan yang masih lajang maupun 
menikah. Hal ini menimbulkan problema peran ganda bagi perempuan yang sudah menikah dan bekerja di dunia perhotelan dimana para pekerja harus membagi waktunya untuk keluarga dan masyarakat. Di satu sisi ia dituntut ikut berpartisipasi dalam masyarakat, sedangkan disisi lain ia di ditakdirkan untuk melaksanakan kodratnya sebagai perempuan (misalnya haid, hamil, melahirkan dan menyusui).

Dalam hal mengkaji isu perempuan yang bekerja tentu terkait dengan isu penyetaraan gender. Gender merupakan pola hubungan atau relasi laki-laki dan perempuan yang didasarkan kepada ciri-ciri sosialnya masing-masing. Termasuk di dalamnya pembagian kerja, pola relasi kuasa perilaku, dan persepsi yang membedakan laki-laki dengan perempuan. Sebagai pranata sosial gender bukan merupakan sesuatu hal yang baku dan tidak berlaku universal dalam artian berbeda dari satu masyarakat ke masyarakat lainnya dan dari waktu ke waktu lain, sehingga dalam pengertian tersebut gender sesungguhnya lebih berkaitan dengan sistem sosial masyarakat dan jauh lebih luas dari sekedar isu perempuan saja ${ }^{1}$

Perempuan sebagai warga negara maupun sebagai sumber daya insani pembangunan, mempunyai kedudukan, hak dan kewajiban, serta kesempatan yang sama dengan pria untuk berpern dalam segala bidang dan tingkatan. ${ }^{2}$ Namun pada kenyataannya pekerja perempuan sangat sulit untuk dapat

1 Hafidz, Wardah. 1995. Pola Relasi Gender dan Permasalahannya. Yogyakarta, h. 12.

2 I Made Udiana, et. al, 2015, Kewajiban Pengusaha Menyediakan Angkutan Antar Jemput Bagi Pekerja/Buruh Perempuan Yang Berangkat Dan Pulang Pada Malam Hari Di Bali Safari And Marine Park, Jurnal Magister Hukum Udayana, Vol 4, No. 3, September 2015, h. 567.

url:https://ojs.unud.ac.id/index.php/jmhu/article/view/18064/11731 diakses pada tanggal 14 Januari 2019 Pukul 22.10 WITA 
kesempatan berkarir yang sama dengan pekerja laki-laki. Pekerja perempuan biasanya dipekerjakan untuk mengerjakan satu jenis pekerjaan tertentu selama bertahun-tahun yang mana hanya dibutuhkan ketekunan, ketelitian, dan kerapihan. Maka dari itu tidak ada kesempatan bagi pekerja perempuan untuk meningkatkan jenjang karir atau promosi jabatan. Selain itu masih banyak kendala yang dihadapi oleh pekerja perempuan sehingga sering disalahartikan atau dipandang kaum perempuan belum dapat bekerja mandiri secara total.

Mempekerjakan perempuan dalam perusahaan tidaklah mudah karena secara fisik sangat berbeda dengan laki-laki yang lebih utama kesusilaan pekerja perempuan wajib dijaga. ${ }^{3}$ Maka dengan demikian terkadang muncul berbagai persoalan seperti bagaimana perempuan bekerja sesuai kodratnya, terlindungi dari pelecehan seksual, perlindungan bagi mereka yang bekerja malam hari, terutama sekali di dunia perhotelan dimana pekerja perempuan yang bekerja dalam operasional hotel yaitu mereka yang bekerja di bagian front office, housekeeping, restaurant, cashier dimana mereka mempunyai jadwal kerja lembur hingga larut malam bahkan hingga pagi serta perlindungan sampai mereka tiba di rumah dengan aman dan selamat.

\subsection{Tujuan}

Tujuan dari penelitian ini adalah untuk mengetahui pelaksanaan perlindungan hukum yang diterapkan perusahaan perhotelan kepada pekerja perempuan yang bekerja di Hotel

3 Diah Fitriani, 2015, Penjabaran Hak Tenaga Kerja Perempuan Atas Upah Dan Waktu Kerja Dalam Peraturan Perusahaan Dan Perjanjian Kerja, Jurnal Magister Hukum Udayana, Vol 4, No. 2, September, 2015, H. 377.

url:https://ojs.unud.ac.id/index.php/imhu/article/view/18064/11731 diakses pada tanggal 14 Januari 2019 Pukul 22.10 WITA 
Besakih Beach Denpasar, serta faktor penghambat pelaksanaan perlindungan hukum bagi pekerja perempuan di sektor perhotelan.

\section{ISI MAKALAH}

\subsection{Metode Penelitian}

Metode penelitian yang digunakan dalam mengkaji Pelaksanaan Pelindungan Hukum Bagi Pekerja perempuan Pada Sektor Perhotelan adalah penelitian hukum empiris. Penelitian hukum empiris yakni penelitian yang dilakukan berangkat dari ditemukannya kesenjangan antara das solen (teori) dengan das sein (kenyataan). Titik tolak pengamatan hukum empiris terletak pada fakta-fakta sosial ataupun kenyataan yang ada dan hidup di tengah-tengah masyarakat sebagai budaya hidup masyarakat. ${ }^{4}$

\subsection{Hasil dan Analisis}

\subsubsection{Pelaksanaan perlindungan hukum bagi pekerja perempuan pada Hotel Besakih Beach Denpasar}

Peraturan perundang-undangan yang mengatur perlindungan hukum bagi pekerja adalah Undang-Undang No. 13 Tahun 2003 Tentang Ketenagakerjaan. Perlindungan terhadap tenaga kerja merupakan hak yang dimiliki oleh tiap-tiap pekerja yang memuat hak-hak dasar pekerja untuk menjamin perlakuan non diskriminasi dan menjamin kesejahteraan maupun keselamatan pekerja serta untuk mewujudkan perkembangan di dunia usaha dan juga demi melindungi kepentingan pengusaha.

4 Bahder Johan Nasution, 2016, Metode Penelitian Hukum, Mandar Maju, Bandung, h. 125. 
Philipus M. Hadjon, menyebutkan "Perlindungan hukum selalu berkaitan dengan kekuasaan yang selalu menjadi perhatian, yakni kekuasaan pemerintah, permasalahan perlindungan hukum bagi rakyat (yang diperintah) terhadap perintah (yang memerintah). Dalam hubungan dengan kekuasaan ekonomi, permasalahan perlindungan hukum adalah perlindungan bagi si lemah (ekonomi) terhadap si kuat (ekonomi), misalnya perlindungan bagi penggarap tanah terhadap pemilik (tuan tanah). 5

Perlindungan bagi tenaga kerja dapat dibedakan menjadi tiga macam $^{6}$ :

1. Perlindungan Ekonomis atau Jaminan Sosial, yaitu bentuk perlindungan pekerja dalam penghasilan yang cukup, termasuk bila tenaga kerja tidak bekerja diluar kehendaknya.

2. Perlindungan Sosial atau Kesehatan Kerja, yaitu bentuk perlindungan tenaga kerja dalam jaminan kesehatan kerja, dan kebebasan berserikat dan perlindungan hak untuk berorganisasi.

3. Perlindungan Teknis atau Keselamatan Kerja, yaitu bentuk perlindungan tenaga kerja dalam upaya memberi keamanan dan keselamatan.

Ketiga bentuk perlindungan di atas merupakan hal mutlak yang harus dilaksanakan oleh pelaku usaha. Jika terdapat pelanggaran yang dilakukan oleh pelaku usaha maka akan

5 R. Indiarsoro dan Mj. Saptemo, 1996, Hukum Perburuhan (Perlindungan Hukum Bagi Tenaga Kerja dalam Program Jaminan Sosial Tenaga Kerja), Karunia, Surabaya, h. 12.

6 Zainal Asikin, 2002, Dasar-Dasar Hukum Perburuhan, Raja Grafindo Persada, Jakarta, h. 76 
dijatuhi sanksi. Selain itu ada beberapa hal yang harus diperhatikan, mengingat hal-hal sebagai berikut: ${ }^{7}$

a. Perempuan pada umumnya dianggap memiliki tenaga yang lemah namun halus.

b. Norma-norma susila harus lebih diperhatikan untuk mencegah terjadinya perbuatan negatif oleh lawan jenis yang dapat menggangu pekerja perempuan.

c. Pekerja perempuan pada umumnya mengerjakan pekerjaan yang halus sesuai dengan kehalusan sifat dan tenaganya.

d. Para pekerja perempuan umumnya memiliki tanggung jawab rumah tangga yang berbeda-beda karena ada yang sudah menikah maupun masih gadis.

Pelaksanaan perlindungan kerja yang diberikan oleh Hotel Besakih Beach Denpasar terhadap pekerja perempuan sesuai dengan Undang-Undang Nomor 13 Tahun 2003 Tentang Ketenagakerjaan, yaitu:

1. Pekerja yang bekerja lembur harus berumur 18 (delapan belas) tahun.

Berdasarkan wawancara dengan I Gusti Gede Tantra, sebagai Personal Manager Hotel Besakih, "para pekerja yang mendapat jam lembur baik itu laki-laki maupun perempuan harus berumur rata-rata 20 sampai 25 tahun" (wawancara pada tanggal 05 April 2017) Para pegawai Hotel Besakih Beach Denpasar dalam mempekerjakan pekerja yang lembur atau tambahan waktu pada malam hari, ini sesuai dengan Pasal 76 ayat (1) Undang-Undang Nomor 13 Tahun 2003 Tentang Ketenagakerjaan.

${ }^{7}$ Gunawi Kartasapoetra et. al, 2008, Hukum Perburuhan Pancasila Bidang Pelaksanaan Hubungan Kerja, Amrico Bandung, h. 43. 
2. Waktu istirahat atau cuti

Pekerja yang bekerja di Hotel Besakih Beach Denpasar memperoleh waktu istirahat selama satu hari dalam waktu satu minggu secara bergiliran seperti yang sudah diatur dalam jadwal oleh manajemen Hotel Besakih Beach Denpasar. Cuti diperoleh oleh pekerja yang bekerja minimal selama 1 tahun dan cuti yang diberikan adalah 14 hari dalam 1 tahun, cuti tersebut dapat digunakan minimal sebanyak 2 kali dan cuti diajukan setidaknya sebulan sebelumnya dengan memberitahukan kepada manajemen hotel atau dengan memberikan surat pengajuan cuti. Hal tersebut telah sesuai dengan Pasal 79 Undang-Undang Nomor 13 Tahun 2003 Tentang Ketenagakerjaan.

Berdasarkan wawancara Ni Wayan Santiwati sebagai Supervisor housekeeping Hotel Besakih bahwa "pihak Hotel Besakih Beach Denpasar menyediakan kotak pertolongan pertama pada kecelakaan (selanjutnya disingkat menjadi P3K), dengan demikian apabila terdapat pekerja yang sakit pada saat bekerja pada jam lembur ataupun di malam hari maka dapat mengajukan izin dengan menyertai surat keterangan dari dokter. Bila terdapat pekerja yang sakit hingga masuk rumah sakit maka pihak hotel berkebijakan untuk memberikan uang intensif dalam meringgankan biaya pengobatan pekerja. Khusus bagi pekerja perempuan yang sedang dalam kondisi hamil bekerja di malam hari.

Hal ini sesuai dengan Pasal 76 ayat (2) Undang-Undang Nomor 13 Tahun 2013 Tentang Ketenagakerjaan yang berbunyi: Pengusaha dilarang mempekerjakan pekerja/buruh perempuan hamil yang menurut keterangan dokter berbahaya bagi kesehatan dan keselamatan kandungannya maupun dirinya apabila bekerja antara pukul 23.00 sampai dengan pukul 07.00. 
3. Upah bagi pekerja

Di Hotel Besakih Beach Denpasar dalam pembagian upah antara tenaga kerja dibagi berdasarkan jabatan yang dipegang. Besaran upah pokok dan tunjangan tetap pekerja di Hotel Besakih Beach sesuai dengan besaran upah minimum regional Denpasar yakni sebesar Rp. 2.173.000,-. Disamping itu pekerja mendapatkan tunjangan tidak tetap seperti tunjangan hari raya, Tunjangan hari raya pada umumnya diberikan oleh pengusaha kepada pekerja menjelang hari raya keagamaan pekerja guna meringankan beban pekerja akibat banyak pengeluaran bagi pekerja dalam menjalankan hari raya keagamaannya. ${ }^{8}$ Jadi pekerja perempuan maupun pekerja laki-laki mendapatkan minimal upah perbulan sekitar Rp. 2.300.000,-. Sedangkan bila jabatannya lebih tinggi maka tunjangan tetapnya berbeda dan maksimal upah yang diterima oleh pekerja perbulan sekitar Rp. 2.800.000,--

Ini membukti bahwa Hotel Besakih Beach Denpasar sudah memberikan upah sesuai dengan Peraturan Gubernur Bali Nomor 67 Tahun 2016 Tentang Upah Minimum Kabupaten/Kota yang menyebutkan Upah Minimum Kabupaten/Kota (selanjutnya disebut UMK) Denpasar tahun 2016 sebesar Rp. 2.173.000,-. Maka Hotel Besakih BeachDenpasar sudah sesuai dengan Pasal 88 ayat 2 Undang-Undang Nomor 13 tahun 2003 Tentang Ketenagakerjaan yang menyatakan bahwa: Untuk mewujudkan penghasilan yang memenuhi penghidupan yang layak bagi kemanusiaan sebagaimana yang dimaksud dalam ayat (1),

8 I Wayan Agus Vijayantera, 2016, Pengaturan Tunjangan Hari Raya Keagamaan Sebagai Hak Pekerja Setelah Diterbitkan Peraturan Menteri Tenaga Kerja Nomor 6 Tahun 2016, Kertha Patrika, Volume 38, Nomor 1, Januari-April 2016, h. 145.

url:https://ojs.unud.ac.id/index.php/kerthapatrika/article/download/30091/1 8463 diakses pada tanggal 14 Januari Pukul 22.56 WITA 
pemerintah menetapkan kebijakan pengupahan yang melindungi pekerja/buruh. Karena bagaimanapun juga upah merupakan sarana untuk meningkatkan kesejahteraan tenaga kerja ataupun pegawai. 9

\section{Uang Lembur}

Berdasarkan wawancara dengan Anak Agung Oka Eryati sebagai Accountant Payroll (sub bidang penggajian), bagi para pekerja yang melakukan jam lembur diluar jam kerja yang seharusnya maka pihak Hotel Besakih Beach Denpasar memberikan uang lembur, sebagai penunjang dan motivasi para pekerja untuk tetap memberikan pelayanan yang prima (hasil wawancara tanggal 10 April 2017) hal tersebut telah sesuai dengan Pasal 78 ayat (2) Undang-Undang Nomor 13 Tahun 2003 Tentang Ketenagakerjaan yang menyatakan bahwa : Pengusaha yang mempekerjakan pekerja/buruh melebihi waktu kerja sebagaimana dimaksud dalam ayat (1) wajib membayar upah kerja lembur. (wawancara tanggal 5 April 2017)

\section{Tempat Ibadah bagi tenaga kerja dan wifi}

Berdasarkan wawancara dengan Ni Wayan Santiwati sebagai Supervisor Housekeeping Hotel Besakih, Hotel Besakih Beach Denpasar menyediakan tempat ibadah bagi para tenaga kerja yang ingin melakukan ibadah (seperti Musolah dan Pura). Pihak hotel juga memberikan fasilitas berupa jaringan Wireless Fidelity (yang kemudian disingkat menjadi Wifi) untuk para tamu yang menginap agar tamu merasa lebih nyaman dengan adanya fasilitas internet yang cepat di hotel. (wawancara pada tanggal 5 April 2017)

${ }^{9}$ Astri Wijayanti, 2009, Hukum Ketenagakerjaan Pasca Reformasi, Penerbit Sinar Grafika, Jakarta, h. 107. 
6. Menjaga kesusilaan dan keamanan di tempat kerja

Ketika pekerja perempuan harus bekerja pada pada malam hari bahkan sampai harus lembur, terkadang banyak resiko yang akan dihadapi seperti misalnya adanya stigma negatif pada pekerja perempuan tersebut di masyarakat maupun kadang bisa ada perlakuan tidak menyenangkan dari tamu yang menginap. Oleh karena itu Hotel Besakih Beach Denpasar menyediakan:

a. Petugas keamanan di tempat kerja

Hotel Besakih Beach Denpasar menyediakan tim security berjumlah 7 orang. Dengan tugas-tugas keamanan tersebut nantinya dapat melindungi pekerja perempuan dan pekerja laki-laki yang bertugas. Hal ini sesuai dengan Pasal 5 huruf a Keputusan Menteri Tenaga Kerja dan Transmigrasi Republik Indonesia Nomor: KEP.224/MEN/2003 Tentang Kewajiban Pengusaha yang Mempekerjakan Pekerja/Buruh Perempuan Antara Pukul 23.00 Sampai Dengan 07.00, menyebutkan bahwa: pengusaha wajib menjaga keamanan dan kesusilaan pekerja/buruh perempuan dengan menyediakan petugas keamanan ditempat kerja. Selain itu, pihak Hotel Besakih Beach juga memasang perangkat sistem keamanan seperti Closed Circuit Television yang mengawasi setiap ativitas di Hotel Besakih Beach Denpasar selama 24 jam/hari.

b. Pakaian

Hotel Besakih Beach Denpasar menyediakan baju seragam agar pekerja berpakaian sopan, pakaian yang diberikan itu berupa baju kemeja dan celana panjang untuk laki-laki, sedangkan untuk perempuan berupa baju kemeja dan rok dibawah lutut. Diharapkan melalui kebijakan tersebut para pegawai Hotel Besakih Beach Denpasar dapat menjaga kesusilaan terhadap pekerjanya sesuai dengan Pasal 76 ayat 
(3) huruf b Undang-Undang Nomor 13 Tahun 2003 Tentang Ketenagakerjaan, yang berbunyi: pengusaha yang mempekerjakan pekerja/buruh perempuan antara pukul 23.00 sampai dengan pukul 07.00 wib menjaga kesusilaan dengan keamanan ditempat kerja.

c. Kamar mandi

Dari hasil pengamatan di Hotel Besakih Beach Denpasar, disediakan toilet berbeda/terpisah untuk pekerja perempuan dan pekerja laki-laki. Selain untuk kenyamanan hal ini juga demi menjaga keamanan pekerja perempuan. Hal tersebut telah sesuai dengan Pasal 5 huruf b Keputusan Mentri Nomor : KEP.224/MEN/2003Tentang Kewajiban Pengusaha yang Mempekerjakan Pekerja/Buruh Perempuan Antara Pukul 23.00 Sampai Dengan 07.00, menyatakan bahwa : Pengusaha wajib menjaga keamanan dan kesusilaan pekerja perempuan dengan menyediakan kamar mandi/wc yang layak dengan penerangan yang memadai serta secara terpisah antara pekerja perempuan dengan pekerja laki-laki.

\subsubsection{Kendala - kendala dalam pelaksanaan perlindungan hukum terhadap pekerja perempuan pada Hotel Besakih Beach Denpasar}

Tenaga kerja sebagai faktor kunci dalam operasional kerja dan usaha sebuah perusahaan mempunyai peranan yang krusial sebagai penunjang untuk keberhasilan usaha yang dijalankan. Pekerja dan pengusaha secara bersama-sama merupakan penopang perusahaan, karena perusahaan merupakan pengelola sedang para pekerja merupakan pelaksananya, karena itulah pendapatan bersih dari hasil usahanya selayaknya dinikmati 
secara bersama dengan bagian yang layak, adil, dalam keserasian. ${ }^{10}$

Mitra hubungan antara pekerja dan pengusaha yang berlandaskan pada demokratisasi di tempat kerja merupakan fenomena dala suatu kegiatan usaha. Jika pekerja dan pengusaha menghendaki kegiatan usahanya maju dan berkembang serta dapat bersaing dalam tataran nasional maupun internasional, dengan demikian mitra hubungan antara pekerja dan pengusaha untuk meningkatkan kemajuan perusahaan. Untuk itu di satu pihak kaum pekerja wajib bekerja secara produktif, di lain pihak pengusaha harus memperhatikan upah dan remunerasi kaum pekerja agar mereka hidup layak. ${ }^{11}$

Dalam memberikan perlindungan terhadap pekerja perempuan, terdapat beberapa faktor kendala dalam pelaksanaan perlindungan hukum terhadap pekerja perempuan di Hotel Besakih Beach Denpasar seperti:

a. Hari kerja di Hotel Besakih Beach melampaui hari kerja yang diatur didalam Undang-Undang Nomor 13 Tahun 2003 Tentang Ketenagakerjaan

Menurut I Gusti Gede Tantra, sebagai Personal Manager Hotel Besakih disebutkan bahwa, hari kerja di Besakih Beach Hotel melampaui hari kerja yang diatur dalam UU Ketenagakerjaan, hal ini terjadi dikarenakan banyaknya pekerjaan yang harus diselesaikan oleh pekerja di hotel tersebut yaitu untuk melayani para tamu Hotel dan

10 I Made Udiana, 2015, Kedudukan dan Kewenangan Pengadilan Hubungan Industrial, Udayana University Press, Denpasar, h. 36.

11 I Made Udiana, 2018, Industrialisasi \& Tanggung Jawab Pengusaha Terhadap Tenaga Kerja Terlibat Hukum, Udayana University Press, Denpasar, h. 58. 
memberikan pelayanan yang terbaik. Hal ini dikarenakan sebagai Hotel Bintang Tiga, Hotel Besakih Beach menambah hari kerja bagi para pekerja untuk mengoptimalkan pelayanan.

Mengingat hotel harus tetap beroperasi pada hari libur, karena justru pada hari libur hotel mendapat kunjungan yang lebih banyak dari hari-hari biasanya. Untuk itu Hotel Besakih tetap mempekerjakan pekerjanya baik laki-laki maupun perempuan pada hari-hari libur walaupun secara bergiliran. Dalam mempekerjakan pekerja pada hari libur, Hotel Besakih Beach memberikan ganti kerugian berupa DP (Day of Payment) untuk membayar hari libur, dimana pada waktu seharusnya libur, namun mereka tetap bekerja.

Terhadap penambahan waktu kerja sewaktu-waktu memang diperlukan mengingat sektor perhotelan merupakan sektor yang memiliki waktu kerja yang padat. Oleh karena menumpuknya pekerjaan yang harus segera diselesaikan oleh pekerja, penambahan waktu kerja memang dapat disetujui asalkan telah ada kesekapatan dari pihak pekerja dan perusahaan. Kesepakatan itupun hanya bersifat sementara dengan penambahan waktu kerja yang terbatas.

Selain adanya faktor eksternal, faktor intern juga menyebabkan penambahan waktu kerja. Pekerja yang tempat tinggalnya tidak dekat dengan tempat kerja kurang disiplin sehingga menyebabkan terlambat dan waktu menyelesaikan pekerjaan juga bertambah lama. Padahal mengenai keterlambatan telah diatur dalam perjanjian kerja.

Pada Hotel Besakih, penambahan waktu kerja pekerja perempuan sewaktu-waktu diperlukan terutama pada front 
office. Hal ini dikarenakan bagian front office merupakan bagian yang berhubungan langsung dengan tamu, memberikan informasi kepada tamu yang datang dan menerima pendaftaran. Penambahan waktu kerja juga kerap diberlakukan jika pada waktu pergantian sifht pekerja yang seharusnya bertugas tidak masuk. Kondisi tersebut dilaksanakan karena sebelumnya telah ada kesepakatn bersama dan adanya imbalan berupa tambahan upah yang seimbang. (wawancara pada tanggal 05 April 2017)

b. Pekerja perempuan tidak mengetahui atau menyadari adanya perlindungan hukum yang diberikan kepada mereka.

Berdasarkan wawancara dengan $\mathrm{Ni}$ Wayan Santiwati sebagai Supervisor Housekeeping dan I Wayan Ayu Bintang Anggreni sebagai Nite Audit Accountant Hotel Besakih, disebutkan bahwa walaupun telah adanya kesepakatan kerja bersama yang dimiliki oleh perusahaan yang didalamnya mengatur tentang perlindungan hukum bagi tenaga kerja perempuan, beberapa pekerja perempuan di Besakih Hotel belum menyadari adanya perlindungan hukum bagi mereka. Hal ini dikarenakan sebagian besar pekerja perempuan tersebut memiliki motivasi kerja dan melaksanakan kewajiban hanya untuk memperoleh upah guna memenuhi kebutuhan keluarga tanpa menyadari dan mau memanfaatkan hak-hak yang mereka peroleh.

Selain itu adanya kemajuan dibidang teknologi kedokteran yang dapat menghasilkan obat pereda nyeri karena haid juga dapat menjadi solusi mengurangi rasa sakit yang 
disebabkan oleh haid sehingga pekerja perempuan tidak perlu mengajukan cuti. (wawancara pada tanggal 05 April 2017)

Dari data-data tersebut di atas, menunjukkan bahwa sudah atau belum terlaksananya pelaksanaan perlindungan hukum bagi pekerja perempuan bukan saja berasal dari pihak hotel melainkan dari pihak pekerja itu sendiri. Loyalitas pekerja terhadap pekerjaannya juga menjadi kendala belum sepenuhnya pelaksanaan perlindungan hukum terhadap tenaga kerja perempuan dapat berjalan. Sebagian besar pekerja perempuan tidak menggunakan hak-hak yang seharusnya mereka peroleh sebagai perlindungan hukum yang mereka terima.

\section{PENUTUP}

\subsection{Kesimpulan}

Berdasarkan uraian pembahasan diatas, maka ditarik kesimpulan dari permasalahan yang diteliti yaitu sebagai berikut:

1. Bahwa bentuk pengaturan perlindungan hukum yang dilaksanakan oleh pihak Hotel Besakih Beach terhadap pekerja perempuan yaitu berupa pembagian waktu kerja, pemberian cuti bagi pekerja perempuan yang hamil hingga melahirkan, sistem pengupahan, waktu istirahat, kesusilaan, uang lembur, keamanan serta kesempatan melakukan ibadah menurut agama dan keyakinan masing-masing.

2. Bahwa kendala yang dihadapi dalam pelaksanaan perlindungan hukum bagi pekerja perempuan bukan saja dari pihak perusahaan namun juga dari pihak pekerja. Kendala dari pihak perusahaan yaitu hari kerja di Hotel Besakih Beach melampaui hari kerja yang sudah diatur Undang-undang karena banyaknya pekerjaan yang harus diselesaikan oleh pekerja di Hotel tersebut. Serta kendala dari pekerja itu sendiri 
adalah sebagian besar pekerja perempuan di Hotel Besakih Beach Denpasar kurang menyadari dan tidak menggunakan hak-hak dari perlindungan hukum yang mereka peroleh.

\subsection{Saran}

Penulis memberikan saran kepada pemilik Hotel Besakih Beach Denpasar sebagai upaya dalam memberikan solusi dalam beberapa rumusan masalah penelitian agar memberikan perlindungan hukum yang sesuai dengan Undang-Undang Nomor 13 Tahun 2003 Tentang Ketenagakerjaan yaitu:

1. Untuk kelancaran hubungan kerja antara pihak Hotel Besakih dengan pekerja perempuan, pihak hotel perlu membenahi dan menegaskan kembali dalam Kontrak Kerja Bersama (KKB) mengenai aturan hak-hak pekerja perempuan mengenai perlindungan hukumnya agar sesuai dengan peraturan perundang-undangan yang berlaku.

2. Memberi penjelasan kepada pekerja perempuan walaupun memiliki motivasi kerja yang tinggi demi memperoleh upah guna memenuhi kebutuhan pokok maupun kebutuhan keluarganya, pekerja perempuan juga harus diberikan pengertian mengenai pentingnya menggunakan hak-hak perlindungan hukum yang mereka diperoleh.

\section{DAFTAR PUSTAKA}

\section{Buku-Buku}

Asikin, Zainal, 2002, Dasar-Dasar Hukum Perburuhan, Raja Grafindo Persada, Jakarta.

Hafidz, Wardah. 1995. Pola Relasi Gender dan Permasalahannya. Yogyakarta, h. 12

Gunawi, Kartasapoetra, Dkk, 2008, Hukum Perburuhan Pancasila Bidang Pelaksanaan Hubungan Kerja, Amrico, Bandung. 
I Made Udiana, 2015, Kedudukan dan Kewenangan Pengadilan Hubungan Industrial, Udayana University Press, Denpasar. , 2018, Industrialisasi \& Tanggung Jawab Pengusaha Terhadap Tenaga Kerja Terlibat Hukum, Udayana University Press, Denpasar.

Indiarsoro, Mj. Saptemo, 1996, Hukum Perburuhan (Perlindungan Hukum Bagi Tenaga Kerja dalam Program Jaminan Sosial Tenaga Kerja), Karunia, Surabaya

Nasution, Bahder Johan, 2016, Metode Penelitian Ilmu Hukum, Mandar Maju, Bandung.

Wijayanti, Astri, 2009, Hukum Ketenagakerjaan Pasca Reformasi, Penerbit Sinar Grafika, Jakarta.

\section{Jurnal Ilmiah}

Diah Fitriani, 2015, Penjabaran Hak Tenaga Kerja Perempuan Atas Upah Dan Waktu Kerja Dalam Peraturan Perusahaan Dan Perjanjian Kerja, Jurnal Magister Hukum Udayana, Vol 4, No. 2, September, 2015, H. 377. url:https://ojs.unud.ac.id/index.php/jmhu/article/view/180 $\underline{64 / 11731}$

I Made Udiana, et. al, 2015, Kewajiban Pengusaha Menyediakan Angkutan Antar Jemput Bagi Pekerja/Buruh Perempuan Yang Berangkat Dan Pulang Pada Malam Hari Di Bali Safari And Marine Park, Jurnal Magister Hukum Udayana, Vol 4, No. 3, September 2015, h. 567.

url:https://ojs.unud.ac.id/index.php/jmhu/article/view/180 $\underline{64 / 11731}$

I Wayan Agus Vijayantera, 2016, Pengaturan Tunjangan Hari Raya Keagamaan Sebagai Hak Pekerja Setelah Diterbitkan Peraturan Menteri Tenaga Kerja Nomor 6 Tahun 2016, Kertha Patrika, Volume 38, Nomor 1, Januari-April 2016, h. 145. url:https://ojs.unud.ac.id/index.php/kerthapatrika/article/d ownload/30091/18463

\section{Peraturan Perundang-Undangan}

Undang-Undang Dasar Negara Republik Indonesia Tahun 1945.

Kitab Undang-Undang Hukum Perdata. 
Undang-Undang Republik Indonesia Nomor 13 tahun 2003 Tentang Ketenagakerjaan, Lembaran Negara Republik Indonesia Tahun 2003 Nomor 39, Tambahan Lembaran Negara Republik Indonesia Nomor 4279.

Peraturan Menteri Tenaga Kerja Nomor PER-03/Men/1994 Tentang Penyelenggaraan Program Jaminan Sosial Tenaga Kerja Bagi Tenaga Kerja Harian Lepas, Tenaga Kerja Borongan dan Tenaga Kerja Kontrak.

Peraturan Menteri Keuangan Nomor 252/PMK.03/2008 Tentang Petunjuk Pelaksanaan Pemotongan Pajak Atas Penghasilan Sehubungan Dengan Pekerjaan, Jasa, dan Kegiatan Orang Peribadi.

Keputusan Menteri Tenaga Kerja dan Transmigrasi Republik Indonesia Nomor: KEP.224/MEN/2003 Tentang Kewajiban Pengusaha yang Mempekerjakan Pekerja/Buruh Perempuan Antara Pukul 23.00 Sampai Dengan 07.00.

Peraturan Gubernur Bali Nomor 69 Tahun 2014 Tentang Upah Minimum Kabupaten/Kota. 